\title{
Comparison of Deoxyribonucleic Acid Homologies of Six Strains of Ammonia-Oxidizing Bacteria
}

\author{
MARK S. DODSON, ${ }^{1}$ JERROME MANGAN, ${ }^{1 *}$ AND STANLEY W. WATSON ${ }^{2}$ \\ Department of Biology, California State University, Fresno, California $93740,{ }^{1}$ and Woods Hole \\ Oceanographic Institution, Woods Hole, Massachusetts $02543^{2}$
}

\begin{abstract}
We assessed polynucleotide sequence homologies among representative strains from four genera of ammonia-oxidizing bacteria, including three morphological types of the genus Nitrosomonas, by deoxyribonucleic acid-deoxyribonucleic acid hybridization. Our results indicate that there is little homology among the four genera which we examined. Furthermore, the low degree of homology among the morphological types of Nitrosomonas suggests that each type should be considered a separate species.
\end{abstract}

Current classification of the ammonia-oxidizing bacteria is based upon the cellular morphologies and fine structures of axenic strains (18). Except for the sodium chloride requirements of marine strains, physiological and biochemical criteria are unsuitable for characterizing these obligate chemoautotrophs (17). Although Nitrosomonas europaea does incorporate certain amino acids at low concentrations, the presence of organic compounds in the growth medium generally inhibits growth $(7,8,16)$.

The four genera of ammonia-oxidizing bacteria recognized in Bergey's Manual of Determinative Bacteriology, 8th ed. (18), are Nitrosomonas, Nitrosococcus, Nitrosolobus, and Nitrosospira. A fifth genus, Nitrosovibrio, has been isolated and described recently (12). Of these genera, only Nitrosococcus contains more than one species $(14,20)$.

The genus Nitrosomonas has been the most extensively studied of these nitrifying bacteria. Watson and Mandel recognized three types within this genus based on differences in the morphologies and fine structures of 13 strains (19). Watson has suggested that these morphological types may represent different species, although only one species, Nitrosomonas europaea, is currently recognized $(17,20)$. The serological diversity of Nitrosomonas strains suggests that there may be more than one species (3).

Watson and Mandel separated the four recognized genera into two groups based upon differences in deoxyribonucleic acid (DNA) base composition (19). One group, with an average guanine-plus-cytosine $(\mathrm{G}+\mathrm{C})$ content of 49.0 mol\%, included the genus Nitrosococcus and the three morphological types of the genus $\mathrm{Ni}$ trosomonas. The second group had an average $\mathrm{G}+\mathrm{C}$ content of $54.3 \mathrm{~mol} \%$ and included the genera Nitrosolobus and Nitrosospira. The
DNA base composition of the genus Nitrosovibrio has not been reported. In an attempt to clarify the taxonomy of this group of bacteria, we performed reciprocal DNA base sequence homology experiments with representative strains of the genera Nitrosococcus, Nitrosolobus, and Nitrosospira and the morphological types of Nitrosomonas.

\section{MATERIALS AND METHODS}

Bacterial strains. The following strains of ammoniaoxidizing bacteria were used in this study: Nitrosomonas europaea $\mathrm{C}-31^{\mathrm{T}}$ (type strain) (= ATCC $25978^{\mathrm{T}}$ ), C-91 (= ATCC 25984), and C-15 (= ATCC 25981), which were isolated from soil, sewage, and seawater, respectively; Nitrosococcus oceanus C-27, which was isolated from seawater; Nitrosolobus multiformis $\mathrm{C}-71^{\mathrm{T}}$ (= ATCC $25196^{\mathrm{T}}$ ), which was isolated from soil; and Nitrosospira briensis $\mathrm{C}-128$, which was isolated from soil. The cells were grown and harvested as previously described (19) at the Woods Hole Oceanographic Institution. The cells were shipped in dry ice to California State University, Fresno, where the reassociation experiments were performed.

Preparation of DNA. The DNA was prepared essentially as described by Crosa et al. (11). Cells ( $1 \mathrm{~g}$ ) were thawed and suspended in $1.5 \mathrm{ml}$ of $0.05 \mathrm{M}$ tris(hydroxymethyl)aminomethane hydrochloride $(\mathrm{pH} \mathrm{8.0)}$. Then the cells were centrifuged at $3,000 \mathrm{rpm}$ in a Sorvall HB-4 rotor for 5 min and lysed by suspending them in $2.5 \mathrm{ml}$ of buffer and adding sodium dodecyl sulfate to a concentration of $2.5 \%$. The resulting lysate was heated at $60^{\circ} \mathrm{C}$ for $10 \mathrm{~min}$ and then rapidly cooled to room temperature. An equal volume of phenol [redistilled, adjusted to $\mathrm{pH} 8.0$ with $\mathrm{NaOH}$, and saturated with 0.1 M tris(hydroxymethyl)aminomethane hydrochloride, $\mathrm{pH}$ 8.0] was added to the lysate, which was then rapidly shaken for $15 \mathrm{~min}$. An equal volume of chloroform-isoamyl alcohol (24:1) was added, and the mixture was shaken for an additional $15 \mathrm{~min}$. After centrifugation at $4,000 \mathrm{rpm}$ for $5 \mathrm{~min}$, the supernatant was collected and treated again with phenol and chloroform. The DNA was precipitated with 2 volumes of $95 \%$ ethanol, collected onto a glass rod, and rinsed 
thoroughly with $95 \%$ ethanol. The DNA was suspended in buffer and treated sequentially with $50 \mu \mathrm{g}$ of ribonuclease (Calbiochem) per $\mathrm{ml}$ for $30 \mathrm{~min}$ at $60^{\circ} \mathrm{C}$ and for $60 \mathrm{~min}$ at $37^{\circ} \mathrm{C}$ and then with $50 \mu \mathrm{g}$ of pronase (Calbiochem) per $\mathrm{ml}$ for $60 \mathrm{~min}$ at $37^{\circ} \mathrm{C}$. After two more phenol and chloroform treatments, the DNA was precipitated with 2 volumes of $95 \%$ ethanol, washed thoroughly, and stored in buffer at $-20^{\circ} \mathrm{C}$.

Labeling DNA by nick translation. A modification of the method of Balmain and Birnie (2) was used to label the DNA. A $200-\mu \mathrm{Ci}$ quantity of $\left[{ }^{3} \mathrm{H}\right]$ thymidine triphosphate $(73 \mathrm{Ci} / \mathrm{mmol}$; ICN) in $50 \%$ ethanol was dried and dissolved in $95 \mu$ l of reaction mixture. Each reaction mixture contained $35 \mu \mathrm{M}$ adenosine triphosphate, $35 \mu \mathrm{M}$ cytosine triphosphate, $35 \mu \mathrm{M}$ guanosine triphosphate, $3.5 \mu \mathrm{M}$ thymidine triphosphate, $1.1 \times$ $10^{-4} \mathrm{M}$ ethylenediamine-tetraacetate, and $1.0 \times 10^{-3}$

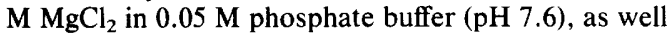
as $103 \mathrm{U}$ of DNA polymerase I (a gift from David Anderson, California Institute of Technology) per $\mathrm{ml}$ and $1 \times 10^{-4} \mu \mathrm{g}$ of deoxyribonuclease I (Sigma Chemical Co.) per $\mathrm{ml}$.

The reaction was started by adding $1 \mu \mathrm{g}$ of DNA which had been dialyzed for $14 \mathrm{~h}$ against $0.05 \mathrm{M}$ phosphate buffer ( $\mathrm{pH} 7.6)$ so that the final volume of the reaction mixture was $100 \mu$ l. The reaction was allowed to proceed for $31.5 \mathrm{~h}$ at $12^{\circ} \mathrm{C}$ and then was terminated by adding $25 \mu \mathrm{l}$ of $0.4 \mathrm{M}$ ethylenediaminetetraacetate, followed by heating to $65^{\circ} \mathrm{C}$ for $10 \mathrm{~min}$. Sonically treated calf thymus DNA (Sigma) was added as a carrier, and the mixture was extracted twice with distilled water-saturated phenol. The mixture was loaded onto a column $(0.9$ by $8.0 \mathrm{~cm})$ of Sephadex G75 and eluted with distilled water. A total of 25 fractions $(0.53 \mathrm{ml}$ each) were collected, and the radioactivity of the labeled DNA was determined by counting 1- $\mu$ l samples from each fraction in ACS (Amersham Corp.) scintillation cocktail. The ascending peak fractions were pooled and treated by a modification of the hydroxyapatite method of Brenner et al. (5) to remove foldback complexes. The labeled DNA was briefly sonicated (20 s at a power setting of $1.9 ; 50 \%$ duty cycle; Branson model 200 Sonifier cell disruptor equipped with a tapered microtip) and then adjusted to a phosphate buffer concentration of $0.12 \mathrm{M}$ ( $\mathrm{pH} 6.8)$ The DNA was boiled for $10 \mathrm{~min}$ and placed in a $60^{\circ} \mathrm{C}$ water bath for $5 \mathrm{~min}$, and the phosphate buffer concentration was reduced to $0.03 \mathrm{M}$ with distilled water at $60^{\circ} \mathrm{C}$. The DNA was then loaded onto the hydroxyapatite $(0.5 \mathrm{~g}$; equilibrated with $0.03 \mathrm{M}$ phosphate buffer, pH 6.8) at $60^{\circ} \mathrm{C}$, mixed, and centrifuged in a tabletop centrifuge at $60^{\circ} \mathrm{C}$. After the DNA was washed once with $2 \mathrm{ml}$ of $0.03 \mathrm{M}$ phosphate buffer, it was eluted from the hydroxyapatite with four $2-\mathrm{ml}$ quantities of $0.12 \mathrm{M}$ phosphate buffer at $60^{\circ} \mathrm{C}$. The first two fractions were pooled and dialyzed against distilled water for $18.5 \mathrm{~h}$. The DNA preparation was adjusted to an $\mathrm{NaCl}$ concentration of $0.42 \mathrm{M}$, and the DNA was sheared by ultrasonic treatment to an average size of approximately 500 base pairs and stored at $-20^{\circ} \mathrm{C}$.

Nucleic acid hybridization. A modification of the S1 endonuclease method of Crosa et al. (10) was used to characterize hybrid DNA duplexes. Each unlabeled DNA preparation was dialyzed for $72 \mathrm{~h}$ against distilled water and adjusted to an $\mathrm{NaCl}$ concentration of $0.42 \mathrm{M}$, and the DNA was sheared by ultrasonic treatment to an average size of 500 base pairs or less.
Each reassociation mixture contained labeled DNA $\left(7,000 \mathrm{cpm}\right.$; approximately $\left.1 \times 10^{-3} \mu \mathrm{g}\right)$ and $30 \mu \mathrm{g}$ of unlabeled DNA in $0.5 \mathrm{ml}$ of $0.42 \mathrm{M} \mathrm{NaCl}$ in a capped polypropylene test tube. The mixtures were denatured by boiling for $10 \mathrm{~min}$ and then incubated for $26.5 \mathrm{~h}$ at $65^{\circ} \mathrm{C}$. After incubation, the mixtures were shifted to $50^{\circ} \mathrm{C}$, and $50 \mu \mathrm{g}$ of sheared, denatured calf thymus DNA and $0.05 \mathrm{ml}$ of a solution containing $1 \times 10^{-3} \mathrm{M}$ $\mathrm{ZnCl}_{2}, 0.06 \mathrm{M}$ sodium acetate buffer ( $\mathrm{pH} 4.6$ ), and 250 $\mathrm{U}$ of $\mathrm{S} 1$ endonuclease (Miles Laboratories, Inc.) were added to each one. After $20 \mathrm{~min}$ of incubation, the reaction was terminated by chilling on ice and adding 1 $\mathrm{ml}$ of cold $10 \%$ trichloroacetic acid. The precipitated DNA was collected onto Whatman GF/A glass fiber filters, rinsed three times with $1 \mathrm{ml}$ of trichloroacetic acid and twice with $1 \mathrm{ml}$ of $95 \%$ ethanol, and then dried at $65^{\circ} \mathrm{C}$ before counting in ACS scintillation cocktail.

When possible, reassociation experiments were performed in triplicate. The following controls were also included. All controls were mixtures containing labeled DNA $(7,000 \mathrm{cpm})$ and $30 \mu \mathrm{g}$ of sheared calf thymus DNA in $0.5 \mathrm{ml}$ of $0.42 \mathrm{M} \mathrm{NaCl}$. One set of controls was denatured, incubated, and treated with S1 endonuclease. Radioactive counts from this set of controls were subtracted as background values from the counts obtained for the hybridization mixtures and represented the degree of self-reassociation of the labeled DNA. The second set of controls was treated as described above but did not receive any $\mathrm{S} 1$ endonuclease. The radioactive counts from this set of controls represented the maximum amounts of recoverable DNA and were used to calculate the extent of reassociation for each hybridization mixture. The extent of polynucleotide sequence homology was determined by taking the ratio of average counts in S1-treated samples to average counts in untreated controls and then normalizing to the homologous reassociation values (11).

Determination of DNA base contents. The $\mathrm{G}+\mathrm{C}$ content of each strain was determined in duplicate by $\mathrm{CsCl}$ buoyant density centrifugation (15). Bacillus subtilis ATCC 23856, Bacillus cereus ATCC 14579, and Micrococcus luteus ATCC 4698 were the sources of the DNAs used as internal standards.

\section{RESULTS}

Hybridizations. The values for DNA homology among the strains used in this study were all quite low (Table 1). Approximately $20 \%$ homology was detected between Nitrosomonas europaea strains $\mathrm{C}-31^{\mathrm{T}}$ and C-91. The third Nitrosomonas europaea strain (strain C-15) showed negligible homology with all of the other strains tested, including the two other Nitrosomonas europaea strains. Approximately $9 \%$ homology was found between Nitrosolobus multiformis strain C- $71^{\mathrm{T}}$ and Nitrosospira briensis strain C128. All other reassociation values between strains were less than $3 \%$. The extents of homologous reassociation ranged from 54 to $79 \%$ under the conditions which we used. Subsequent experiments (data not shown) with strains $\mathrm{C}-31^{\mathrm{T}}, \mathrm{C}-91, \mathrm{C}-128$, and $\mathrm{C}-71^{\mathrm{T}}$, in which we used 
TABLE 1. DNA base compositions and degrees of DNA homology among strains

\begin{tabular}{|c|c|c|c|c|c|c|c|c|}
\hline \multirow{2}{*}{$\begin{array}{c}\text { Source of } \\
\text { unlabeled } \\
\text { DNA }\end{array}$} & \multirow{2}{*}{$\begin{array}{c}\mathrm{G}+\mathrm{C} \\
\text { content } \\
(\mathrm{mol} \%)^{a}\end{array}$} & \multicolumn{6}{|c|}{ Degree of homology $(\%)$ with index (labeled) DNA from strain: ${ }^{b}$} & \multirow{2}{*}{$\begin{array}{l}\text { \% Reassociation } \\
\text { of homologous } \\
\text { reassociation } \\
\text { mixture }\end{array}$} \\
\hline & & $\mathrm{C}-31^{\mathrm{T}}$ & C-91 & C-15 & $\mathrm{C}-27$ & $C-71^{\mathrm{T}}$ & C-128 & \\
\hline $\mathrm{C}-31^{\mathrm{T}}$ & 52.2 & 100 & 22.8 & 1.1 & 0 & 0.9 & 1.8 & 78 \\
\hline C-91 & 50.0 & 19.2 & 100 & 1.9 & 0 & 1.8 & 1.5 & 75 \\
\hline C-15 & 48.0 & 2.3 & 0.8 & 100 & 0 & 1.7 & 5.8 & 71 \\
\hline C-27 & 50.6 & 1.5 & 1.3 & 1.9 & 100 & 2.1 & 2.9 & 79 \\
\hline C- $71^{\mathrm{T}}$ & 53.7 & 1.9 & 0.6 & 3.8 & 1.2 & 100 & 10.5 & 64 \\
\hline C-128 & 52.5 & 0.2 & 0.1 & 0.1 & 0 & 6.7 & 100 & 54 \\
\hline
\end{tabular}

${ }^{a}$ Mean of duplicate determinations.

${ }^{b}$ Values were obtained by determining the ratio of average counts in S1-treated samples to average counts in untreated controls after subtracting self-reassociation counts and normalizing to homologous reassociation values. Hybridizations were done in triplicate, except for strain C-128 hybridizations, which were done in duplicate.

twice as much unlabeled DNA $(120 \mu \mathrm{g} / \mathrm{ml})$ and Whatman $\mathrm{GF} / \mathrm{C}$ glass fiber filters, resulted in an average increase of $24 \%$ in the homologous reassociation values, but virtually no change in the heterologous values.

DNA base compositions. The results of the $\mathrm{G}+\mathrm{C}$ content determinations are shown in Table 1. The values obtained were similar to those reported by Watson and Mandel (19). Nitrosomonas europaea strains $\mathrm{C}-31^{\mathrm{T}}$ and $\mathrm{C}-91$ showed slightly higher values than previously determined, and the value for Nitrosospira briensis strain C-128 (52.2 mol\%) was slightly lower than the value reported previously for a different Nitrosospira strain (19).

\section{DISCUSSION}

The purposes of this study were to determine whether representative strains of the three morphological types of Nitrosomonas europaea could be separated from one another based upon differences in polynucleotide sequence homologies and to determine whether there are any polynucleotide sequence homologies among the four genera of ammonia-oxidizing bacteria which we examined. In the past, DNA-DNA hybridization studies involving the ammoniaoxidizing bacteria were not easily undertaken due to the difficulties encountered in cultivating this group of organisms (i.e., lengthy generation times, low growth yields, and obligately chemoautotrophic nature). The advent of suitable in vitro methods for radiolabeling DNA has made such studies feasible.

It has been generally accepted that strains of the same species should have polynucleotide sequence homologies of $70 \%$ or more $(1,9,13)$. Homologies ranging from 20 to $60 \%$ have been considered to represent anywhere from "low" (11) to "moderate" (6) to "closely related but separate" species (9).
All of the strains of ammonia-oxidizing used in this study were readily distinguished from one another based upon differences in their polynucleotide sequence homologies. The low degrees of homology observed among the three strains of Nitrosomonas europaea suggest that the three morphological types of Nitrosomonas europaea described by Watson and Mandel represent three separate species. Furthermore, the marine strain of Nitrosomonas europaea, strain C-15, had no more homology with the other two strains of Nitrosomonas europaea than it did with the other three genera which we examined. A more extensive survey involving several more strains from each of the three morphological types of Nitrosomonas europaea is needed to determine whether each type consists of a genetically homologous cluster or whether each of the three morphological types can be further separated into additional species.

Analysis of DNA base compositions has not separated the ammonia-oxidizing bacteria into distinct genera (19). The negligible degrees of polynucleotide sequence homology observed among the four genera which we examined support the morphological criteria that have been used to separate these organisms into distinct genera. However, degrees of relatedness at the genus level are difficult to evaluate by using polynucleotide sequence homologies. Brenner (4) has suggested that "members of a given genus should exhibit a greater level of relatedness to other species in that genus than to members of any other." Thus, further studies involving several strains from each genus of the ammonia-oxidizing bacteria are needed to determine whether polynucleotide sequence homology data support the morphological criteria used to distinguish these genera. It may well be that the marine strajin of Nitrosomonas europaea belongs not just in a different species but in a separate genus, as its levels of homology with 
the other strains of Nitrosomonas europaea are so low. It is noteworthy that the two morphologically distinct genera Nitrosolobus and Nitrosospira showed a higher degree of homology with each other than did Nitrosomonas europaea strain C-15 with morphologically similar strains $\mathrm{C}-31^{\mathrm{T}}$ and C-91.

\section{ACKNOWLEDGMENTS}

We thank E. E. Harding for her interest and advice in the preparation of the manuscript and David M. Anderson for the DNA polymerase I used in this study.

We gratefully acknowledge the Dean's Office, School of Natural Sciences, California State University, Fresno, for some of the funding for this work.

\section{LITERATURE CITED}

1. Aulakh, H. S., S. E. Straus, and K. J. Kwon-Chung. 1981. Genetic relatedness of Filobasdiella neoformans (Cryptococcus neoformans) and Filobasdiella bacillispora (Cryptococcus bacillisporus) as determined by deoxyribonucleic acid base composition and sequence homology studies. Int. J. Syst. Bacteriol. 31:97-104.

2. Balmain, A., and G. D. Birnie. 1979. Nick translation of mammalian DNA. Biochim. Biophys. Acta 561:155-166.

3. Belser, L. W., and E. L. Schmidt. 1978. Serological diversity within a terrestrial ammonia-oxidizing population. Appl. Environ. Microbiol. 36:589-593.

4. Brenner, D. J. 1973. Deoxyribonucleic acid reassociation in the taxonomy of enteric bacteria. Int. J. Syst. Bacteriol. 23:298-307.

5. Brenner, D. J., G. R. Fanning, A. V. Rake, and K. E. Johnson. 1969. Batch procedure for thermal elution of DNA from hydroxyapatite. Anal. Biochem. 28:447-459.

6. Brenner, D. J., J. J. Farmer III, G. R. Fanning, A. G. Steigerwalt, P. Klykken, H. G. Wathen, F. W. Hickman, and W. H. Ewing. 1978. Deoxyribonucleic acid relatedness of Proteus and Providencia species. Int. J. Syst. Bacteriol. 28:269-282.

7. Clark, C., and E. L. Schmidt. 1967. Uptake and utilization of amino acids by resting cells of Nitrosomonas europaea. J. Bacteriol. 93:1309-1315.

8. Clark, C., and E. L. Schmidt. 1967. Growth response of
Nitrosomonas europaea to amino acids. J. Bacteriol. 93:1302-1308.

9. Coykendall, A. L., and A. J. Munzenmaier. 1978. Deoxyribonucleic acid base sequence studies on glucan-negative strains of Streptococcus mitior. Int. J. Syst. Bacteriol. 28:511-515.

10. Crosa, J. H., D. J. Brenner, and S. Falkow. 1973. Use of a single-strand-specific nuclease for analysis of bacterial and plasmid deoxyribonucleic acid homo- and heteroduplexes. J. Bacteriol. 115:904-911.

11. Crosa, J. H., B. L. Williams, J. J. Jorgensen, and C. A. Evans. 1979. Comparative study of deoxyribonucleic acid homology and physiological characteristics of strains of Peptococcus saccharolyticus. Int. J. Syst. Bacteriol. 29:328-332.

12. Harms, H., H. P. Koops, and H. Wehrmann. 1976. An ammonia-oxidizing bacterium, Nitrosovibrio tenuis nov. gen. nov. sp. Arch. Microbiol. 108:105-111.

13. Johnson, J. L. 1973. Use of nucleic acid homologies in the taxonomy of anaerobic bacteria. Int. J. Syst. Bacteriol. 23:308-315.

14. Koops, H. P., H. Harms, and H. Wehrmann. 1976. Isolation of a moderate halophilic ammonia-oxidizing bacterium, Nitrosococcus mobilis nov. sp. Arch. Microbiol. 108:277-282.

15. Mandel, M., C. O. Schildkraut, and J. Marmur. 1968. Use of density gradient analysis for determining base content. Methods Enzymol. 12B:184-195.

16. Watson, S. W. 1965. Characteristics of a marine nitrifying bacterium, Nitrosocystis oceanus sp. n. Limnol. Oceanogr. 10:274-289.

17. Watson, S. W. 1971. Taxonomic considerations of the family Nitrobacteraceae Buchanan: request for opinions. Int. J. Syst. Bacteriol. 21:254-270.

18. Watson, S. W. 1974. Gram-negative chemolithotrophic bacteria. Family I, p. 450-456. In R. E. Buchanan and N. E. Gibbons (ed.), Bergey's manual of determinative bacteriology, 8 th ed. The Williams \& Wilkins Co., Baltimore.

19. Watson, S. W., and M. Mandel. 1971. Comparison of the morphology and deoxyribonucleic acid composition of 27 strains of nitrifying bacteria. J. Bacteriol. 107:563-569.

20. Watson, S. W., F. W. Valois, and J. B. Waterbury. 1981. The family Nitrobacteraceae, p. 1006-1061. In M. P. Starr, H. Stolp, H. G. Trüper, A. Balows, and H. G. Schlegel (ed.), The prokaryotes, a handbook on habitat, isolation, and identification of bacteria. Springer Verlag, New York. 